\title{
$\mathbf{G}$

\section{Entrepreneurship Challenges in High-Growth Companies and Consequences for SME Policy}

\author{
Robert K. Gruenwald
}

\begin{tabular}{|c|c|}
\hline \multirow{2}{*}{\multicolumn{2}{|c|}{$\begin{array}{l}\text { A B S T R A C T } \\
\text { Objective: The objective of this paper is to identify success factors for corporate } \\
\text { growth out of these two approaches (hidden champions research, high-growth } \\
\text { companies research) to make the findings fertile for entrepreneurship policy and for } \\
\text { entrepreneurship with a growth focus. }\end{array}$}} \\
\hline & \\
\hline \multicolumn{2}{|c|}{$\begin{array}{l}\text { Research Design \& Methods: The article is based on the literature review } \\
\text { (theoretical background and research results on high-growth companies). The paper } \\
\text { is a summary of recent research findings regarding SME growth drivers and success } \\
\text { factors as well as considerations about the goals of an effective SME and } \\
\text { entrepreneurship policy. }\end{array}$} \\
\hline \multicolumn{2}{|c|}{$\begin{array}{l}\text { Findings: On the basis of the various empirical research only } 6 \text { to } 10 \% \text { of companies } \\
\text { become high-growth companies. Most high-growth companies arise in niche } \\
\text { markets in low-involvement industries and are not breakthrough innovators or } \\
\text { technology leader. These companies produce the most jobs. }\end{array}$} \\
\hline \multicolumn{2}{|c|}{$\begin{array}{l}\text { Implications \& Recommendations: Therefore, it is recommended in terms of SME } \\
\text { policy not to generally support high technology or 'trendy' industries or more or less } \\
\text { evenly many companies, but to use research findings for better targeting the } \\
\text { companies with the highest potential to become outperformer and 'jog engines'. }\end{array}$} \\
\hline \multicolumn{2}{|c|}{$\begin{array}{l}\text { Contribution \& Value Added: The paper can be treated as a unique summary of the } \\
\text { 'state of research' about successful SMEs and the application of the research } \\
\text { findings to an economic policy question (interdisciplinary approach). }\end{array}$} \\
\hline Article type: & \\
\hline Keywords: & \\
\hline & \\
\hline
\end{tabular}

\section{Suggested citation:}

Gruenwald, R.K., (2013). 'Entrepreneurship Challenges in High-Growth Companies and Consequences for SME Policy'. Entrepreneurial Business and Economics Review, 1(1), pp. 41-55. 


\section{INTRODUCTION}

Herrmann Simon (1990) coined the concept of hidden champions (heimliche/unbekannte Gewinner). This approach is one model for the analysis of highgrowth companies, i.e. companies that outperform the market; however, only a few important empirical studies have been conducted to testify this approach, mostly focusing on German companies. There is nowhere else such a comparably high number of so-called hidden champions - usually owner-managed companies that are European or world leaders in narrow market niches and thus sustainable high-growth companies. Furthermore, in previous years, some surveys have been published on 'high-growth companies' (HGC) or 'high-growth entrepreneurship' (HGE), also analysing growth drivers of SMEs in other countries than Germany.

The objective of this paper is to identify success factors for corporate growth out of these two approaches to make the findings fertile for entrepreneurship policy and for entrepreneurship with a growth focus. The paper is based on a literature review regarding hidden champions, SME success factors, and high-growth entrepreneurship. From the perspective of SME/entrepreneurship research, the relevance of the topic is in possible answers to the questions:

- What is the state of research on managing corporate growth?

- Are there comparable success patterns in the findings of various surveys, which may be useful for entrepreneurs and entrepreneurship policy?

From the perspective of SME/entrepreneurship policy the relevance is a possible answer to the question:

- What kind of companies has the most potential to generate jobs and is therefore the Archimedean point of an effective SME/entrepreneurship policy?

\section{LITERATURE REVIEW}

\section{Managing Corporate Growth in HGCs from the German Perspective}

Concepts of growth are in frequently linked implicitly or explicitly to the model of corporate life cycle (CLC). This approach is based on a biological metaphor of living organisms, which have a regular pattern of development of 'birth', 'growth', 'maturity', 'decline' and 'death' (Sihler et al., 2004, p.3; Wach, 2012, p. 48-49). The CLC is a model proposing that businesses, overtime, progress through a fairly predictable sequence of developmental stages. Five of the more popular models are that of Greiner (1972), Churchill \& Lewis (1983), Scott \& Bruce (1987), Burns \& Dewhurts (1996), and Sihler et al. (2004).

The CLC approach can be seen as descriptive (Dobbs \& Hamilton, 2006, p. 298). It sums up the different levels of operations and financial management complementary to distinct stages of a company's growth and the use of both internal and external resources (Sautet, 2003, p. 88; Haric et al., 2013, p. 49). A more strategic and less descriptive view of growth is delivered by the success factor research following the PIMS (profit impact on market strategy/share) approach and the hidden-champions approach. Whereas the PIMS approach considers the conquest of market shares in mass markets as strategic focus for growth, the hidden champions' approach emphasizes the growth in niche markets where companies are not exposed to intense competition, but are even protected by the narrowness of the market (in terms of 
market volume) against the entry of "big players", a thereby following intensified competition and price erosion through price war, and low margins.

Both approaches tend to be normative in the sense their aim is not only 'producing descriptions' but also delivering management recommendations. While the PIMS findings are mostly generated by surveying large enterprises in mature markets or on the maturity stage of the CLC (Thomas \& Gup, 2010, p. 23; Woywode, 2004, p. 16), the hidden champions approach focuses on mid-sized companies (Simon 2012, p. 143).

In addition to the studies of Simon, other research on German medium-sized companies which are European or world market leaders still exists. In particular, consulting firms such as McKinsey, Ernst \& Young and Droege \& Company have researched in the same direction: The publications of Meffert \& Klein (2008) (McKinsey), Ernst \& Young (2008), Age \& Kalkbrenner (2010) or of Blommen \& Bothe (2008) are examples of this trend to examine success factors of German mid-sized companies. Three recent and comprehensive surveys covering German growth companies are:

a) Hidden Champions Panel in the years 1990-2012 (Simon, 1996; 2007; 2012).

b) The McKinsey SME Survey 2007 (Meffert \& Klein, 2008).

c) The KfW Survey 2004 (Bindewald, 2004).

\section{RESULTS AND DISCUSSION}

SME Growth Drivers: Simon's Hidden Champions Panel (1996, 2007 and 2012)

In the 1990s, Hermann Simon (1990; 1996) conceptualized the category of companies that he called hidden champions. Since 1990, he has analysed leading companies in a panel whose sample includes approximately 1316 companies. This sample consists of firms which are (1) no. 1, 2 or 3 in their markets, in terms of their revenues in relation to the total market volume, have (2) their revenue less than 3 billion EUR, and are (3) usually not stock-listed companies (i.e. the companies' management is not subject to short-term profit interests) and are typical entrepreneurial companies (Simon, 2007, p. 29). The main findings of the Simons research in terms of growth drivers are:

- In terms of Ansoff's growth strategy matrix, hidden champions initially target usually only a single market segment with a single-product strategy: Hidden champions are in the take-off and growth phase usually a one-product company. Frequently, the market is established only by the hidden champions (Simon, 2012, p. 128).

- At the level of market stimulation strategies, hidden champions strive for lasting quality leadership in terms of customer orientation and product properties and can thus realize a price premium. Therefore, hidden champions cannot be forced into margin-reducing price wars, but can grow sustainably by profiting from profitable customer segments without margin-reducing pricing strategies (Simon, 2012, p. 143).

- The high specialization by strict market segmentation leads to a volumetrically very 'narrow' lasting market; therefore, they must pursue an internationalization strategy relatively early in the CLC to tap from quickly narrowing home markets as the growth limit (Simon, 2012, p. 187). 
- Hidden champions focus not on what can be set off in the market now or what new arisen market segments offer in terms of growth rates (opportunistic behavior, metoo-strategy). They thus do not have the classic view of the management. This is evident not at least in the fact that they even often establish markets, or that they occupy market niches that are ignored, or even regarded as unattractive and which belong to the low-involvement industries (Simon, 2012, p. 160; Rasche, 2003, p. 220).

- In the case of hidden champions, innovation means mostly not new technology, but process innovation, innovation in distribution, logistics, marketing and sales and design (Simon, 2007, pp. 191-193). So, a Hidden Champion is not 'breakthrough innovation' company.

\section{SME Growth Drivers: McKinsey German Leading Companies Survey (2006)}

The McKinsey survey on German leading companies is based on the McKinsey data base, as well as on interviews with CEOs of 800 companies out of the data set. The survey segment represents the most successful segment of the German economy. The companies of this segment are characterized by an annual sales growth of $4.6 \%$ and an average 5\% return on sales in the period from 1998 to 2003.

The success of a leading company cannot be explained by the right market choice or with the selection of the right entry strategy (Meffert \& Klein, 2007, p. 187). Instead, a specific company development path is typical for leading companies. McKinsey developed, out of the survey data, an own CLC model. Successful companies starting as specializers then become cost leaders or innovation leaders. From both stages, some companies manage to make the transformation to a competence leader in later phases of the CLC.

The strategy change from the specializer to the competence leader takes at least 10 years and is frequently not straight. Compared to the cost leader, the specializer, the innovation champion and competence leader have a significant higher average profit margin (Meffert \& Klein, 2007, p. 70).

\section{SME Growth Drivers: KfW Entrepreneurial Success Germany Survey 2004}

The KfW is, with total assets of 495 billion EUR (2011), the third largest German bank. The banking group covers over $90 \%$ of its borrowing needs in the capital markets. The $\mathrm{KfW}$ Mittelstandsbank ( $\mathrm{KfW}$ small and medium enterprises bank), the second largest business unit of the $\mathrm{KfW}$ group, provides assistance to German SMEs, including individual entrepreneurs and start-ups. In addition to loans, it also provides equity and mezzanine financing. Its financing totalled 24.1 billion EUR in 2012. The KfW offers financing for entrepreneurship, enterprise development and innovation covers the entire CLC. (Touché, 2013, pp. 7, 8, 10, 13)

The KfW survey findings show the following significant differences between failed and surviving companies in a 20-year period (Bindewald, 2004, pp. 57, 68-72, 74-83):

- Successful companies place much higher value on quality management, which is expressed by their significantly higher quality claim.

- Successful companies focus much more on customer loyalty. 
- The success does not depend on the business experience of the company's founding entrepreneur. This is shown in particular in the fact that the segment of ages 25 to 35 is significantly more successful than the segment of ages 35 to 45 .

- Start-up experience is not a success factor: $75 \%$ of the unsuccessful but only $57 \%$ of successful entrepreneurs have had management experience in business start-up.

- The same goes for leadership experience: Former senior executives are even less often successful than former staff employees.

- Successful entrepreneurs also differ significantly in whether they make use of external consulting: About $90 \%$ of the successful company has included external consultants, in the group of failed entrepreneurs, this is true of only about $65 \%$. Therefore, the KfW binds lending to the accompaniment of start-up coaches or to the involvement of management consultants. From the successful entrepreneurs, only $7 \%$ have never taken advice; however, $31 \%$ of unsuccessful companies have never taken advice.

- The entrepreneur's personality traits seem to be insignificant for the company's success. In contrast, corporate planning is an important success factor: Successfully founding companies is highly dependent on sufficient preparation and quality of a business model (business plan).

\section{SME Growth Drivers: Recent International Studies on High-Growth Companies}

In particular, the surveys of McKinsey (Meffert \& Klein, 2007) and Simon (1996; 2007; 2012) have studied success factors of companies that are more advanced in the CLC and have already overcome some barriers to growth. The relatively new concept of "High-Growth Companies" research deals mainly with start-ups and companies in the early growth phase. Two recent meta-analyses summarize the status of research on high-growth companies (Henrekson \& Johansson, 2010; Daunfeld, Elert \& Johansson, 2010): The total of 28 studies on high-growth companies (1988-2007) is largely based on statistical data from the end of the 70s until the mid-2000s. Many surveys deal mainly with the issues of the employment effect of high-growth companies and less on the causes of high growth. Therefore, 10 studies were selected and evaluated, out of the total 28 surveys from 2000 until now (table 1). Further findings of listed surveys are as follow:

- Fast-growing companies generate, on average, significantly more jobs (all studies).

- Fast growth is a rather temporary phenomenon within the CLC (Hölzl, 2009; Acs et al., 2008). Smaller companies have the tendency to grow faster, due to size-related efficiency disadvantages. Therefore, the higher-growth companies are, on average, younger than the slower-growing companies. By contrast, 'young' means not necessarily start-ups: $70 \%$ of the companies with a growth rate of at least $20 \%$ over a 3-year period are at least 5 years old (Acs et al., 2008); instead, companies that have doubled their revenue over 3 years are, on average, 25 years old. Fast-growing companies are not necessarily young companies or start-ups.

- Fast-growing, young companies can be found in all sectors - not just in technology or knowledge-intensive areas (Hölzl, 2009).

- High-growth companies are, on average, older than growth companies in the startup phase (Acs et al., 2008). It can be assumed there is no positive relation between productivity, company age and growth. The assumption that due to the rising 
learning curve, older companies should be more productive than younger ones, turns out to be questionable. The results of López-Garcia \& Puente (2009) show fast-growing companies in the start-up phase have up to $30 \%$ higher productivity than comparable companies of the sector.

- Internationalizing companies grow faster (Henrekson \& Johansson, 2009).

- Better access to debt capital is associated with higher growth (López-Garcia \& Puente, 2009).

- Subsidies are of meaning for kick-starting the founding of a business, but not for initial business growth (Koski \& Pajarinenin, 2010).

Table 1. Selected Studies and Surveys on High-Growth Companies in the years 2000-2010

\begin{tabular}{|c|c|c|c|c|}
\hline Autor/Year & $\begin{array}{l}\text { Time } \\
\text { Period }\end{array}$ & Region & $\begin{array}{l}\text { Sample Group and } \\
\text { Control Group }\end{array}$ & Main Findings \\
\hline $\begin{array}{l}\text { Almus } \\
\text { (2000) }\end{array}$ & $\begin{array}{c}1990- \\
1999\end{array}$ & Germany & $\begin{array}{l}\text { Existing and no } \\
\text { longer existing } \\
\text { companies }\end{array}$ & $\begin{array}{l}\text { In the field of the } 10 \% \text { fastest growing } \\
\text { companies, technology companies and } \\
\text { knowledge-based service providers are } \\
\text { not significantly more successful than } \\
\text { companies with established products of } \\
\text { the "old economy." }\end{array}$ \\
\hline $\begin{array}{l}\text { Autio et al. } \\
(2000)\end{array}$ & $\begin{array}{c}1994- \\
1997\end{array}$ & Finnland & Existing companies & $\begin{array}{c}\text { Fast growing companies (sales growth of } \\
50 \% \text { in three years) increase the number } \\
\text { of employees by approximately } 400 \% \text { in } \\
\text { three years. }\end{array}$ \\
\hline $\begin{array}{l}\text { Brüderl \& } \\
\text { Prisendörfer } \\
\text { (2000) }\end{array}$ & $\begin{array}{c}1985- \\
1990\end{array}$ & Germany & $\begin{array}{c}\text { Since } 1985, \\
\text { established } \\
\text { companies with the } \\
\text { exception of } \\
\text { handicraft } \\
\text { businesses, law } \\
\text { firms, farms and } \\
\text { architects }\end{array}$ & $\begin{array}{l}\text { About } 4 \% \text { of all companies have achieved } \\
\text { a growth in staff of more than } 100 \% \text { in the } \\
\text { survey time period. Conclusion: Only a } \\
\text { small part of all start-ups creates a } \\
\text { significant effect on employment. }\end{array}$ \\
\hline $\begin{array}{l}\text { Acs \& } \\
\text { Müller } \\
\text { (2008) }\end{array}$ & $\begin{array}{c}1990- \\
2003\end{array}$ & USA & $\begin{array}{l}\text { Companies founded } \\
\text { during the } \\
\text { investigation period }\end{array}$ & $\begin{array}{l}\text { High-growth companies develop mainly in } \\
\text { metropolitan regions, since they obviously } \\
\text { find the skills needed for the fast growth } \\
\text { here. }\end{array}$ \\
\hline $\begin{array}{l}\text { Acs et al. } \\
(2008)\end{array}$ & $\begin{array}{l}1994- \\
2006\end{array}$ & USA & $\begin{array}{l}\text { Companies } \\
\text { persistent and } \\
\text { liquidated during } \\
\text { the research period }\end{array}$ & $\begin{array}{l}\text { About } 3 \% \text { of all companies have doubled } \\
\text { their sales over a period of } 3 \text { years. These } \\
\text { companies are responsible for almost all } \\
\text { new jobs created in their region. } \\
\text { The average age of these companies is } 25 \\
\text { years. Older companies tend to weaker } \\
\text { job growth. }\end{array}$ \\
\hline $\begin{array}{l}\text { López- } \\
\text { Garcia \& } \\
\text { Puente } \\
\text { (2009) } \\
\end{array}$ & $\begin{array}{c}1996- \\
2003\end{array}$ & Spain & $\begin{array}{l}\text { Existing small- and } \\
\text { medium-sized } \\
\text { enterprises }\end{array}$ & $\begin{array}{c}\text { Low labor costs increase growth } \\
\text { probability. } \\
\text { High-growth companies have relatively } \\
\text { more long-term debt. }\end{array}$ \\
\hline $\begin{array}{l}\text { Anaydike- } \\
\text { Danes et al. } \\
(2009)\end{array}$ & $\begin{array}{c}1998- \\
2008\end{array}$ & UK & $\begin{array}{l}\text { Existing small- and } \\
\text { medium-sized } \\
\text { enterprises }\end{array}$ & $\begin{array}{l}6 \% \text { of all existing companies are growing } \\
\text { fast, which means they have a sales or } \\
\text { employee growth of } 20 \% \text {. } \\
70 \% \text { of high-growth companies are at } \\
\text { least } 5 \text { years old. }\end{array}$ \\
\hline
\end{tabular}




\begin{tabular}{|c|c|c|c|c|}
\hline $\begin{array}{l}\text { Amat \& } \\
\text { Perramon } \\
(2010)\end{array}$ & $\begin{array}{l}1994- \\
2007\end{array}$ & Spain & $\begin{array}{l}\text { Companies with a } \\
\text { minimum turnover } \\
\text { of } 2.4 \text { million EUR } \\
\text { and a return of } 7 \% \\
\text { on average per year } \\
\text { over a three-year } \\
\text { period }\end{array}$ & $\begin{array}{l}\text { Quality management, innovation focus } \\
\text { and pro-active human resource } \\
\text { management are key success factors, as } \\
\text { well as conservative, long-term oriented } \\
\text { financial management. }\end{array}$ \\
\hline $\begin{array}{l}\text { Koski \& } \\
\text { Pajarinen } \\
\text { (2011) }\end{array}$ & $\begin{array}{l}2003- \\
2008\end{array}$ & Finland & $\begin{array}{l}\text { The } 10 \% \text { of the } \\
\text { fastest growing } \\
\text { start-up companies } \\
\text { from the group of } \\
\text { all companies }\end{array}$ & $\begin{array}{l}\text { Subsidies are not critical to the growth of } \\
\text { companies in the sample, but are } \\
\text { important in the start-up phase. } \\
\text { Therefore, the assumption is that } \\
\text { subsidies and loans increase the } \\
\text { probability of establishing start-ups. }\end{array}$ \\
\hline $\begin{array}{l}\text { Daumfeldt, } \\
\text { Elert \& } \\
\text { Johanson } \\
(2010)\end{array}$ & $\begin{array}{c}1998- \\
2007\end{array}$ & $\begin{array}{l}22 \\
\text { European } \\
\text { countries, } \\
\text { USA, } \\
\text { Canada }\end{array}$ & $\begin{array}{l}\text { Evaluation of } 28 \\
\text { studies on high- } \\
\text { growth companies }\end{array}$ & $\begin{array}{l}\text { Young growth companies create } \\
\text { proportionally more jobs than older ones. } \\
\text { The group of larger growth companies } \\
\text { generated higher percentage growth. }\end{array}$ \\
\hline
\end{tabular}

Source: own compilation

\section{CONCLUSIONS}

High-Growth Entrepreneurship and Implications for SME Policy

Efficiency in entrepreneurship policy and SME policy is, at first, simple to define: to achieve with a given amount the highest outcome. In terms of the topic of this paper, the recommendation may be to find the $6 \%$ to $10 \%$ of the companies with the highest growth potential (high-growth companies), or companies that sustainably outperform the market (hidden champions) or have the potential to sustainably outperform the market (specialisers, innovation champions), because they produce the most jobs. Born Globals or technology leaders are not part of the group of companies that create many jobs. Growth motivation is a necessary factor for actual firm growth.

High-Growth Entrepreneurship is characterised by growth motivation that is determined by the perceived ability, need and opportunity for growth (Davidsson, 1989). Although some objective factors directly affect actual growth, the entrepreneur's perception of the ability, need and opportunity for growth is of major importance for explaining motivation-mediated effects on growth. Therefore, several potential crucial differences between generic entrepreneurship policies (SME policies) and high-growth entrepreneurship policies should be noted (Table 2).

However, scientific study of growth companies is not and will not be an exact science, if it is meant in terms of clear cause-effect relations. Referring, however, to the preliminary considerations on the normativity of economic policy, the findings of recent research on growth companies suggest the impact of the current EU SME policy may be relatively weak and has room for improvement. This means, the conclusion of this paper is not that the EU SME policy is right or wrong, but seems to be inappropriate in terms of the macro-level targets. In the perspective of the analysis executed and presented above, the EU SME policy gives the impression of a scattered bundle of activities, whereas the main topics of the job growth agenda (internationalisation but 
not world market strategy, high-growth in niche markets but not mass market cost leadership, innovation leadership but not technology leadership) are completely underrepresented. Beside this, technology-focused SME policy seems questionable.

Table 2. Trade-Offs between SME and High-Growth Entrepreneurship Policies

\begin{tabular}{|c|c|c|}
\hline Criteria & $\begin{array}{c}\text { SME Policy } \\
\text { Generic Entrepreneurship Policy }\end{array}$ & $\begin{array}{l}\text { High-Growth } \\
\text { Entrepreneurship Policy }\end{array}$ \\
\hline \multicolumn{3}{|c|}{ Policy Goals } \\
\hline $\begin{array}{l}\text { Objectives in relation to } \\
\text { entrepreneurship }\end{array}$ & $\begin{array}{l}\text { Entice more people to become } \\
\text { entrepreneurs }\end{array}$ & $\begin{array}{l}\text { Entice the right people to become } \\
\text { entrepreneurs }\end{array}$ \\
\hline $\begin{array}{l}\text { Objectives in relation to } \\
\text { entrepreneurial firms }\end{array}$ & $\begin{array}{l}\text { Increase the number of new } \\
\text { entrepreneurial firms }\end{array}$ & $\begin{array}{l}\text { Increase the growth of } \\
\text { entrepreneurial firms }\end{array}$ \\
\hline $\begin{array}{l}\text { Objectives in relation to } \\
\text { operational environment }\end{array}$ & $\begin{array}{l}\text { Facilitate the environment for } \\
\text { small business operation }\end{array}$ & $\begin{array}{l}\text { Facilitate the environment for } \\
\text { entrepreneurial firm growth }\end{array}$ \\
\hline \multicolumn{3}{|c|}{ Resource Provision } \\
\hline Source & Mostly from public sources & $\begin{array}{l}\text { Combination of public and private } \\
\text { sources }\end{array}$ \\
\hline Type of financial resources & Grants, subsidies, soft loans & $\begin{array}{l}\text { R\&D loans and innovation grants, } \\
\text { business angel finance, venture } \\
\text { finance, IPOs }\end{array}$ \\
\hline Dominant service & $\begin{array}{l}\text { Basic (standard) advice for firm } \\
\text { creation, business planning, small } \\
\text { business operation }\end{array}$ & $\begin{array}{l}\text { Experienced-based advices for } \\
\text { venture finance, strategic } \\
\text { planning; internationalisation; } \\
\text { organisational growth }\end{array}$ \\
\hline $\begin{array}{l}\text { Resource distribution } \\
\text { principle }\end{array}$ & $\begin{array}{l}\text { Ensure equal access for everyone } \\
\text { (resource spread) }\end{array}$ & $\begin{array}{l}\text { Select promising recipients } \\
\text { (resource focus) }\end{array}$ \\
\hline \multicolumn{3}{|c|}{ Regulatory Emphasis } \\
\hline Lifecycle focus & $\begin{array}{l}\text { Remove bottlenecks to new } \\
\text { business entry }\end{array}$ & $\begin{array}{l}\text { Remove bottlenecks to } \\
\text { entrepreneurial firm growth }\end{array}$ \\
\hline $\begin{array}{l}\text { Compliance bottleneck } \\
\text { addressed }\end{array}$ & $\begin{array}{l}\text { Reduce cost of compliance for } \\
\text { small business }\end{array}$ & $\begin{array}{l}\text { Smooth compliance requirements } \\
\text { for growing firms }\end{array}$ \\
\hline Fiscal regulations & Reduce VAT for small firms & $\begin{array}{l}\text { Accommodate dramatic changes } \\
\text { in firm scale; treat share options } \\
\text { neutrally }\end{array}$ \\
\hline Attitude towards failure & Avoid failure, bankruptcy & $\begin{array}{l}\text { Accept firm failure and } \\
\text { bankruptcy, but reduce the } \\
\text { economic and social cost of these }\end{array}$ \\
\hline $\begin{array}{l}\text { Links to other policy } \\
\text { domains }\end{array}$ & $\begin{array}{l}\text { Industrial policy, social policy, } \\
\text { labor policy }\end{array}$ & $\begin{array}{l}\text { Industrial policy, innovation } \\
\text { policy, labor policy }\end{array}$ \\
\hline
\end{tabular}

Source: (Autio, 2007, p. 38)

According to several findings on high-growth companies, the period of 5 to 25 years seems to be the decisive age of a company (Acs et al., 2008; Anaydike-Danes et al., 2009). At this stage of a company's CLC, it is decided more or less whether a company has the potential to become a high-growth specialiser and innovation champion, and thus grow into a Hidden Champion, or will only follow business and market cycles without steady revenue and job growth. This time period can be referred to as the Archimedean point for SME subsidies, loans, grants, etc. Afterwards, when the shift to the sustainable growth company is completed, a growth company has better access to debt capital (López-Garcia \& Puente, 2009), so that the market may be the better 'expert' to decide what is 'right' or 'wrong' to invest in, as it can be done by 
regional, national or transnational 'experts'. Additionally, it can be asserted that the pre-start-up phase is also an Archimedean point (mostly neglected by funding institutions on the national level (see e.g. Institut für KMU-Management, 2012, p. 10). Subsidies are meant for kick-starting the founding of a business, but not for initial business growth (Koski \& Pajarinenin, 2011). At these two points of the CLC, subsidies and loans may be most efficient. Thereafter, it should be 'the market as Hayek's discovery process', which selects 'good' from 'bad'.

The same applies to technology funding. A growing specialiser is the best proof of a correct assumption on what the market needs and is willing to pay for. Therefore, a technology-dependent loan (thematic funding) or subsidy is, seemingly, not the best way to promote high growth in terms of the free market paradigm. Additionally, the fact that most growth companies arise in low-involvement industries supports this view. This is especially true for the Born Globals. Fast-growing technology companies are precisely not the companies that should be promoted, because they do not create jobs at home. Therefore, it is to ask, whether it is just the high-tech or rather lowinvolvement industries companies (hidden champions) that should be supported.

\section{Financing Entrepreneurship and SME Policy in the European Union}

The current European Union's support to SMEs is available in different forms such as grants, loans and guarantees. The focus on activities is very interesting. It is apparent the largest part of the budget is for regional convergence activities and will be assumedly allocated very fragmentally (probably in thousands) small regional projects with the focus on levelling regional disparities. In contrast, internationalisation and high-growth companies are funded in negligible portions.

The second largest share is for supporting 'non-thematic' innovation (means: not for innovations in the field of environment, energy, or transport), which is primarily technological innovation (i.e., not sales, business models, or other non-technological innovations). Aside from the question of whether only technology innovation drives growth, the question arises here regarding who decides and on what basis the decision is made about whether a proposed innovation is truly marketable at the end of the $R$ \& $D$ process and should therefore be encouraged by loans, subsidies, grants, etc. The answer is: regional authorities. The question then is: Has there been any regional administration expertise in business development, or is there rather a significant risk expected that only particularistic interests of political parties prevail here? This may be the main issue to evaluate the efficiency of the policy approach: Can the regional focus really produce efficient allocation of resources? (OECD, 2007, pp. 78, 93; Wach, 2008, pp. 397-406) Finally, regional disparities are an expression of market developments. Can it be useful to counter this politically, or rather to accept the structural change and to strive for an appropriate re-allocation and focusing of resources on the new or existing regional growth centres, rather than on structurally weak areas and prolonging only decline with tax money? At least, it becomes clear that SME policy needs a more strategic approach. This is at least the conclusion of an Organisation for Economic Cooperation and Development (OECD) evaluation on the impact of SME policies in different countries (OECD, 2007, p. 93). Concerning the EU, this evaluation is supported by further studies (Tödtling-Schönhofer et al., 2011, p. 71). 
It is possible, that particularistic interests on the level of regions and party-bound industrial policy biases may prevent an allocation into growth-sectors and industries or growth companies and may, for instance, support mature industries and companies. This assumption is also supported by the fact that the decision for allocating the budget is made on regional and national levels. In any case, it is not the 'market' that decides. Additionally, it is remarkable that no comparative or quantitative targets are given anywhere in the "European Union Support Programmes for SMEs" (European Commission 2012a).

However, it is evident, that EU SME policy has no clear vision why and what kind of companies should be supported. Instead, the EU SME policy gives the impression that the budget is only distributed in terms of equal distribution without any focus.

\section{Final Remarks and Recommendations}

High-Growth Companies are job engines. Two recent meta-analyses summarise the status of research on high-growth companies (Henrekson \& Johansson, 2010; Daunfeld, Elert \& Johansson, 2010). A total of 28 studies on high-growth companies (1988-2007) are largely based on statistical data from the end of the 1970s until the mid-2000s. Definitions of high-growth companies can be distinguished in terms of criteria growth indicators, measurement methods, time period considered and the introduction of additional criteria. The two most common economic growth indicators are the number of employees and turnover (OECD, 2007, 2008; Fritsch \& Weyh, 2004; Autio, Arenius \& Wallenius, 2000).

The type of growth measurement differs, such as absolute, relative and a combination of absolute and relative growth used as benchmarks. Regarding the measurement period, definitions differ only slightly. The growth period is three years with the majority of the investigations. However, all surveys since 2000 have come to the same results: Fast-growing companies generate, on average, significantly more jobs (Autio, Arenius \& Wallenius, 2000; Brüderl \& Prisendörfer, 2000; Schreyer, 2000; Halabisky et al., 2006; Acs et al., 2008).

Other studies, however, do not make precise quantitative statements, but also come to the result that high-growth companies have a significantly disproportionate share in the creation of new jobs (Ahmad \& Petersen, 2007; Fritsch \& Weyh, 2006; Littunen \& Tohmo, 2003; Davidsson \& Delmar, 2003, 2006).

Efficiency in entrepreneurship policy is, at first, simple to define: to achieve with a given amount the highest outcome. In terms of the topic of this paper, the recommendation may be: find the 6 to $10 \%$ of the companies with the highest growth potential, because they produce the most jobs. However, the scientific study of entrepreneurship is not and will not be an exact science, if it is meant in terms of clear cause-effect relations. The reason for this is neither the entrepreneur nor the firm is a clockwork-like trivial machine. Therefore, correlations between diverse factors are not calculable, and input-output relations with high probabilities of occurrences are not to be expected - a problem, that is also well known from market or economic development forecasts. Therefore, and despite the research on high-growth companies, it is still difficult to identify these $6 \%$ to $10 \%$ of the companies.

However, some indications are given by the compiled research. First, entrepreneurship should be promoted before the company is legally established, and 
after it has established itself in the market and has shown that the business model is really running. In contrast, in the start-up stage, no outcome forecasts are valid. However, the findings show, in particular, that a kick-start for establishing a company depends more on money than on a convincing business model.

Thereafter, it must be 'the market as discovery process' (Hayek), which selects 'good from bad'. However, when the market has valuated the business model and the one-product-company and a company becomes a specializer and not only an 'operator' of existing 'product-money circuits', the possibility is higher that a company can make the next leap to becoming an innovation leader or realizes growth, but with a lower rate and the market or product cycle as a cost leader. However, if the premise of entrepreneurial policy is to be efficient, then only the innovation leader should be the target of loans and subsidies, due to these companies having more sustainable futures with higher independence from market cycles and the fact that it they become highgrowth companies that generate more jobs.

According to recent study findings on high-growth companies, the entrepreneurial crossroads for future growth beyond a cycle of an established market will be reached after at least 5 years. The period of 5 to 25 years seems to be the decisive age of a company. At this stage of the CLC, subsidies and loans may be most efficient. The main instrument for allocating subsidies and loans may be the financial and strategic analysis to answer the question on the average growth rate in the last 3 to 5 years, as well as the financial health and the economic value added to the company and soft facts (e.g., customer relationship status, customer loyalty, customer price elasticity, level of customer care, quality management level, etc.).

The question than is what to promote. First, support should target the promotion of product development and the establishment of professionalism in processes for continuing innovation, strategy controlling, and - maybe most important internationalization.

Concerning loans and subsidies for innovation, the findings compiled above suggest that the question of what an innovation is should not be defined be policy - the market proof is here the better expertise. And a growing company is the best proof of a correct assumption on what the market needs and is willing to pay for. Therefore, a technology dependent loan or subsidy seems not the best way to promote high growth in terms of the free market paradigm. Additionally, the fact that most growth companies arise in low-involvement industries supports this view.

To summarize these short considerations on entrepreneurship policy in light of the findings presented here, it seems necessary to base the promotion of high-growth companies, not on assumptions on technology development and innovation or technology assessments. High-growth companies are neither breakthrough innovation nor high-tech champions. Additionally, research on high-growth companies and success factors will never deliver any forecast models. However, dynamic systems, such as markets or companies, may never be the standard case for causality, but only of pattern and pattern recognition. Therefore, it seems one of the most important desideratum that the big data approach - as it was demonstrated in the case of the $\mathrm{KfW}$ survey - will become the bases for better decision-making in entrepreneurship policy. Additionally, this may be the reason why the $\mathrm{KfW}$ follows this two-step approach: loans and subsidies for kick-starts and for companies on a latter growth 
stage. In this sense, the KfW may be regarded as a model for CLC-compliant promotion of businesses with high-growth potential.

\section{REFERENCES}

Acs, Z. \& Mueller, P., 2008, 'Employment Effects of Business Dynamics: Mice, Gazelles and Elephants', Small Business Economics, vol. 30, no. 1, pp. 85-100.

Acs, Z., Parsons, W. \& Tracy, S., 2008, High-Impact Firms: Gazelles revisited, Small Business Research Summary 328. Corporate Research Board, Washington.

Almus, M., 2000, What characterizes a Fast-Growing Firm? ZEW Discussion Paper 64/2000. ZEW, Mannheim.

Amat, O. \& Perramon, J., 2010, Gazelle companies: growth drivers and an evolution analysis, Universitat Pompeu Fabra Working Paper 1244, Barcelona.

Anyadike-Danes, M., Bonner, K., Hart, M. \& Colin, M., 2009, Measuring Business Growth. Highgrowth Firms and their Contribution to Employment in the UK, Research Report 10/2009, London: NESTA.

Autio, E., 2007, Global Entrepreneurship Monitor 2007. Global Report on High-Growth Entrepreneurship, London: Global Entrepreneurship Research Consortium.

Autio, E., Arenius, P., Wallenius, H., 2000, Economic Impact of Gazelle Firms in Finland, Helsinki University of Technology Working Paper Series 2000.

Autio, E., Sapienza, H., Almeida, J., 2000, 'Effects of Age at Entry, Knowledge Intensity, and Imitability on International Growth', The Academy of Management Journal, vol. 43, no. 5, pp. 909-924.

Bindewald, A., 2004, Unternehmensinsolvenzen in Deutschland und ihre Bedeutung für die volkswirtschaftliche Entwicklung', in Was erfolgreiche Unternehmen ausmacht. Erkenntnisse aus Wissenschaft und Praxis, Bonn: Physica-Verlag, pp. 1-14.

Brüderl, J. \& Preisendörfer, P., 2000, 'Fast Growing Businesses. Empirical Evidence From A German Study', International Journal of Sociology, vol. 30, No. 3, pp. 45-70.

Burns, P. \& Dewhurst J., 1996, Small Business and Entrepreneurship. Hampshire: Basingstoke.

Churchill, N. \& Lewis, V., 1983, 'The five stages of small business growth', Harvard Business Review, vol. 61, no. 3, pp. 30-50.

Daunfeldt, S., Elert, N. \& Johansson, D., 2010, The Economic Contribution Of High-Growth Firms: Do Definitions Matter? The Ratio Institute Working Paper 151. Stockholm.

Davidsson, P., 1989, 'Entrepreneurship and after? A study of growth willingness in small firms', Journal of Business Venturing, vol. 4, pp. 211-226.

European Commission, 2007, Accompanying document to the Communication from the Commission: Raising productivity growth: key messages from the European Competitiveness Report, Commission staff working document SEC (2007) 1444, Brussels.

European Commission, 2012, Europe 2020: Europe's Growth Strategy: Growing to a sustainable and job-rich future, Brussels.

Greiner, L., 1972, 'Evolution and Revolution as Organizations Grow', Harvard Business Review, vol. 50, no. 4, Reprint 98308, 1998.

Haric, P., Pollack, C., Grüblbauer, J. \& Rintersbacher, M., 2013, Ziel Hidden Champions: Handbuch für wachstumsorientierte Unternehmensführung, Vienna: Leitbetriebe Institut. 
Henrekson, M. \& Johansson, D., 2010, 'Gazelles as Job Creators. A Survey and Interpretation of the Evidence', Small Business Economics, vol. 35, pp. 227-244.

Hölzl, W., 2009, 'Is the R\&D Behaviour of Fast-Growing SMEs different? Evidence from CIS III data for 16 countries', Small Business Economics, vol. 33, no. 1, pp. 59-75.

KfW Bankengruppe, 2004, Was erfolgreiche Unternehmen ausmacht: Erkenntnisse aus Wissenschaft und Praxis, Frankfurt.

Koski, H. \& Pajarinen, M. 2011, The Role of Business Subsidies in Job Creation of Start-ups, Gazelles and Incumbents, ETLA Discussion Paper 1246, Helsinki.

López-Garcia, P. \& Puente, S., 2009, What Makes A High-Growth Firm? A Probit Analysis Using Spanish Firm-Level Data, Banco di Espana Working Paper 0920, Madrid.

Meffert, J. \& Klein, H., 2006, DNS der Weltmarktführer. Erfolgsformeln aus dem Mittelstand, Heidelberg: Redline.

OECD, 2007, OECD Framework for the Evaluation of SME and Entrepreneurship Policies and Programmes, OECD Publishing, Paris.

OECD, 2010, High-Growth Enterprises: What Governments Can Do to Make a Difference, OECD Publishing, Paris.

Olderog, T., 2003, Faktoren des Markterfolgs im Online-Handel, Wiesbaden: Deutscher Universitätsverlag/GWV Fachverlag.

Sautet, F., 2003, An Entrepreneurial Theory of the Firm, New York: Routledge.

Schneck, O., 2006, Handbuch alternative Finanzierungsformen, Weinheim: Wiley-VCH.

Scott, M. \& Bruce, R., 1987, 'Five Stages of Growth in Small Business', Long Range Planning, vol. 20 , no. 3, pp. 45-52.

Sihler, W., Crawford, R. \& Davis, H., 2004, Smart financial management, New York NY: American Management Association.

Simon, H., 1990, 'Hidden Champions: Speerspitze der deutschen Wirtschaft', Zeitschrift für Betriebswirtschaft (ZfB), vol. 60, no. 9, pp. 875-890.

Simon, H., 1996, Die heimlichen Gewinner (Hidden Champions): Die Erfolgsstrategien unbekannter Weltmarktführer, Frankfurt/New York: Campus Verlag.

Simon, H., 2007, Hidden Champions des 21. Jahrhunderts, Frankfurt/New York: Campus Verlag.

Simon, H., 2012, Hidden Champions: Aufbruch nach Globalia, Frankfurt/New York: Campus Verlag.

Simon, H., 2012, Hidden Champions: Aufbruch nach Globalia, Frankfurt/New York: Campus Verlag.

Simpson, B.P., 2005, Markets Don't Fail, Oxford: Rowman \& Littlefield Publishers.

Thomas, R. \& Gup, B., 2010, The Valuation Handbook: Valuation Techniques from Today's Top Practioners, Hoboken: Wiley.

Tödtling-Schönhofer, J., Hamza Ch., Resch A., Polverari., L., Bachtler J., 2011, Impact and Effectiveness of Structural Funds and EU Policies Aimed at SMEs in the Region, European Parliament Policy Department Structural and Cohesion Policies - European Parliament, Brussels.

Touché, B., 2013, Aktuelle Entwicklungen der KfW Förderung, KfW Präsentation auf dem b.b.h. Bundeskongress. KfW, Bonn.

Wach, K., 2008, 'Impact of the Regional Business Environment on the Development of Small and Medium-sized Enterprises in Southern Poland', In: R. Borowiecki \& A. Jaki (eds.), Enterprises 
in the Face of 21st Century Challenges. Development - Management - Entrepreneurship, Cracow: Foundation of the Cracow University of Economics, pp. 397-406.

Wach, K., 2012, Europeizacja małych i średnich przedsiębiorstw: rozwój przez umiędzynarodowienie, Warszawa: Wydawnictwo Naukowe PWN.

Woywede, M., 2004, Wege aus der Erfolglosigkeit der Erfolgsfaktorforschung, in: Was erfolgreiche Unternehmen ausmacht. Erkenntnisse aus Wissenschaft und Praxis, ed. KfW Bankengruppe, Bonn: Phyisica-Verlag.

\section{Author}

\section{Robert K. Gruenwald}

Bachelor in Business Administration from the FOM University for Economics and Management (Fachhochschule für Oekonomie und Management, FOM) in Essen (Germany), Master in Accounting and Finance from the FOM University of Economics and Management in Essen (Germany); currently PhD student in Entrepreneurship (Cracow University of Economics, Poland); CEO of eCollect AG (Switzerland), Financial Technology \& Services.

\section{Correspondence to:}

Robert K. Gruenwald, B.A., M.A.

PhD Student at the Cracow University of Economics gruenwald@gmx.ch

Published by Centre for Strategic and International Entrepreneurship - Krakow, Poland 